European journal of American studies

Special Issue: Video Games and/in American Studies:

Politics, Popular Culture, and Populism

\title{
America is Dead. Long Live America! Political Affect in Days Gone
}

Soraya Murray

\section{CpenEdition}

\section{Journals}

Electronic version

URL: https://journals.openedition.org/ejas/17409

DOI: $10.4000 /$ ejas. 17409

ISSN: 1991-9336

Publisher

European Association for American Studies

Electronic reference

Soraya Murray, "America is Dead. Long Live America! Political Affect in Days Gone ", European journal of American studies [Online], 16-3 | 2021, Online since 24 September 2021, connection on 24 September 2021. URL: http://journals.openedition.org/ejas/17409 ; DOI: https://doi.org/10.4000/ejas.17409

This text was automatically generated on 24 September 2021.

Creative Commons License 


\title{
America is Dead. Long Live America! Political Affect in Days Gone
}

\author{
Soraya Murray
}

\section{Introduction}

1 Days Gone (2019) is about navigating a broken road. It is a narrative-driven, open world, action-adventure survival horror game played in the third person, which imagines a post-apocalyptic America. Developed by SIE Bend Studio and published by Sony Interactive Entertainment, Days Gone models a disturbing new "normal" that is overwhelming and insurmountable, which comes in the form of a radical other (the genomically mutated "Freaker"). It is clear all infrastructure has broken down, and only tiny pockets of humanity survive. Set within rural Oregon, a region known for offgrid and separatist communities, the game depicts a power struggle that takes place between settlements representing different values (libertarian, carceral, law-andorder, militaristic, etc.). Encoded as a disaffected white ex-military biker and drifter, player-character Deacon St. John tries to negotiate all of this flawed humanity, while contending with his own damage and collaborating with those communities in order to survive (Figure 1). Traveling country roads and scratching out an existence in an unforgiving environment, Deacon contends with predatory wildlife, harsh land, and weather, and-worst of all-other humans. Play consists of combat, stealth, crafting, scavenging, and navigating the wilderness on a motorcycle that needs constant maintenance and fuel. The game has a strong bent toward extreme self-reliance. More compelling, however, are the complex interlocking systems at work within the game that model the Pacific Northwest landscape as ideology. ${ }^{1}$ Through the harsh environment and its mutated fauna, much is conveyed about a worldview that presumes a deeply troubled and oppositional relation to everyone and everything. As the unsubtle slogan warns, “This world comes for you" (Bend Studio). 


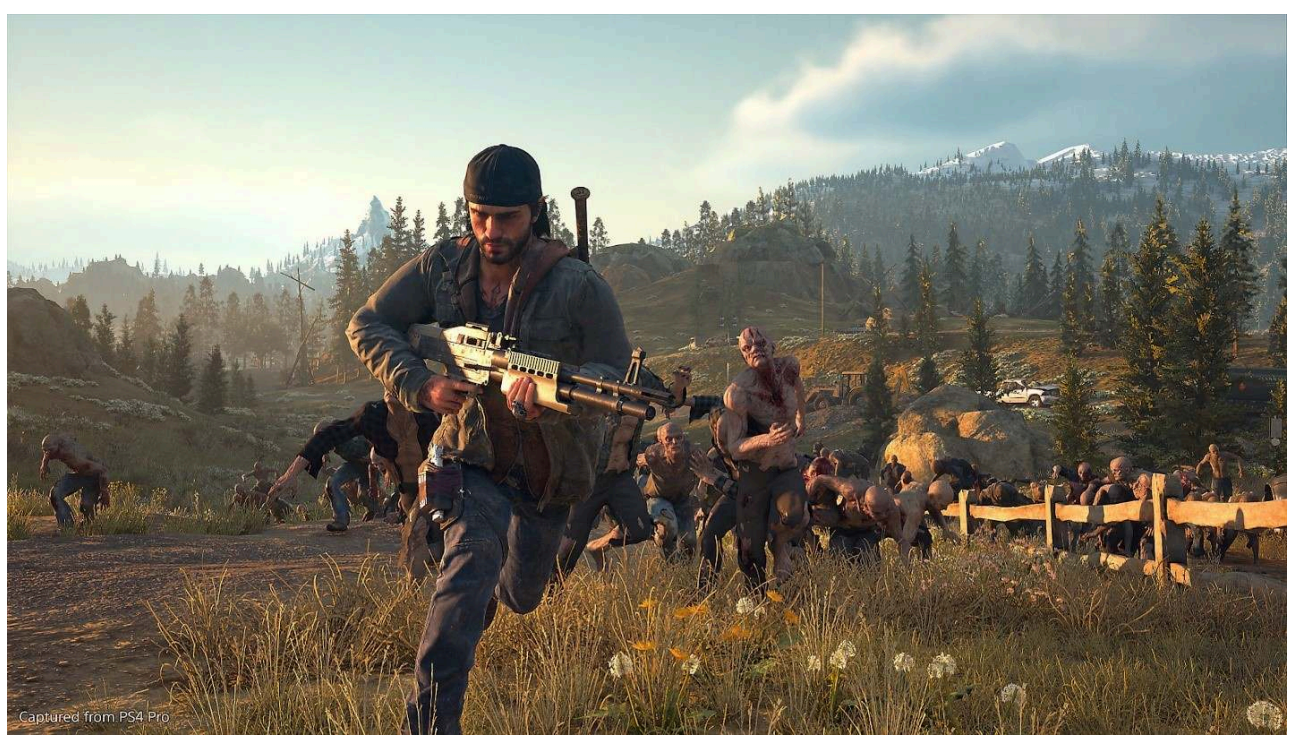

Figure 1.

This game is a difficult object, something to be urgently sat with, rather than dismissed. It is a glimpse into a fantasy of American self-reliance -bordering on the separatistwhich strongly resonates with a nationalist turn in U.S. politics. While this essay contains ideological readings, it also gestures toward a kind of working-through and sitting with a difficult aesthetic object. In terms of a strictly representation-based ideological reading of the game, Days Gone would be an easy target, with its white, male anti-hero and its appropriation of so many of the exhausted tropes of the actionadventure survival horror genre. I am interested in moving away from such an approach, though, not because this interpretation would lack merit. Indeed, in my own previous research, this has been a core investment (Murray, On Video Games). As many of my colleagues and I have argued, video games are now solidly part of a media landscape that contributes to visual literacies. TreaAndrea M. Russworm captures it well, suggesting that, "video games are also powerful simulations that produce artificially constructed imagery or data, and like all imagery, systems, and data, video games disseminate dominant values, beliefs, and assumptions in much the same way that 'fake news,' tweets, memes, and viral videos of police brutality do" (74). Indeed, I am indebted to the influence of British cultural studies, particularly the work of Stuart Hall. These representations and the ideologies they reinforce do matter, particularly in regard to toxic undercurrents that have been identified by many scholars of games (Everett et al.; Malkowski and Russworm; Gray and Leonard). However, the kind of open-world gameplay Days Gone offers is also tied to a deeply affective, spatio-temporal experience-one which I have also argued can lead to insights about the game rooted in the durational traversing of space. This is an effort to reach through the offending image and grasp the political affect that emanates from aesthetic experience.

What stands out here is precisely the game's use of the sublime and its strategic mobilization of the generic, to effect a very specific sense of political feeling. By "political feeling" or "political affect" I'm signaling a diffuse structure of what Ann Cvetkovich has described as "relations between the emotional, the cultural and the political," particularly as it touches "the everyday experience of sensation and embodiment as ways of tracking [the] intersection of the social and the psychic" (Staiger et al. 5-6). I'm interested here in how this affective component can gather up 
intensities, something scholar Deborah Gould sees as the "bursting with potential" quality of affect (Gould et al.; see also Gould). In my own writing, I sometimes call this "political affective intensities."

4 Being rooted in the arts, and particularly visual culture, I want to acknowledge the influence of scholar, critic, and curator Jennifer Doyle in her important work on how politically overdetermined forms of experience-particularly on the affective level-are negotiated by artists and their audiences (Doyle). I should be clear that, like Doyle, I do not place affect and ideology at opposite poles, but agree that it is in the space of aesthetically borne emotion that "ideology does its most devastating work" (Doyle xi). I am in deep accord, as well, with her strategically nebulous definition of affect. She writes:

I use the terms emotion, feeling, and affect rather loosely. In general, I privilege the words emotion and feeling over affect when describing how people experience works, and use affect to highlight the diffuse nature of emotion and feeling, in which a mood can saturate a space, for example, or in which an institutional setting such as a museum might impose its own set of rules regarding proper comportment, expressivity, and emotionality. (146)

5 Like Doyle, I experience my cultural object of study through instances of being pushed out and pulled in by its affective dimensions. Days Gone draws me in as a cultural object that speaks to its moment as evidently worth consideration, yet as a game it profoundly pushes me out in terms of the demands it places upon me as a player who is not oriented toward its ideologies. But, again, I am pulled in by the sense that this video game evidences something that is of consequence to understand; namely, it is one aesthetic manifestation of a turn away from neoliberal global expansion, and toward nationalism and self-reliance.

6 Aubrey Anable's Playing With Feelings, an ambitious bringing together of game studies and affect theory, has also been extremely productive for this conversation (Anable). She writes, "Analyzing how a video game feels and how it can put us into a particular affective relation to history is a "phenomenologically imprecise" method. It opens game studies up to other affective attachments, histories, and ways of being in relation to video games" (6). While her work is focused on game examples that are decidedly gendered as feminine in the popular imaginary (i.e. bound up in things like "feeling" or coded as "casual" mobile games as opposed to the more male-coded "hardcore" console games), how the affective, spatio-temporal experience works on the players of mainstream video games matters, too. ${ }^{2}$

7 In this regard, I'm interested in how traversing the space and time of the game's landscape contributes to its overall affective charge, and how the very atmosphere of the game may spatially communicate particular impressions. Sara Ahmed has discussed the spatiality and directionality of affect, its role in shaping what falls within our "bodily horizon" of likes and dislikes ("Multiculturalism" 125-26). Though she does not speak of video games specifically, I want to also recognize Ahmed's notion of spatiality in terms of her construct of orientation toward or against particular things. She discusses this in relation to the "kill-joy" who "refuses to share an orientation toward certain things as being good because she does not find the objects that promise happiness to be quite so promising" ("Happy Objects" 39). Pushed out and pulled in by the affective dimensions of Days Gone, I am aware that this "kill-joy" dynamic is certainly at work, in even the very act of identifying this game (intended for fun, play, and entertainment) as a difficult object. 
In relation to video games, Anable frames affect as both "affective interfaces" from their earliest instantiation in the history of computers, and key to bridging the divide in an old and tired form/content debate that has plagued game studies (24). While less interested in conventional matters of media representations in terms of superficial inclusion, Anable explores the links between affect and representation, and how games become an archive of a way of life. She writes:

video games-their images, sounds, stories, mechanics, and interfaces-can be read and interpreted as giving shape and form to particular feelings. Video games are not technologies capable of autonomously and unconsciously rewiring our bodies; rather, they are a particularly popular form of representation through which we can trace and analyze how affect moves across bodies and objects in the present. (132)

9 It is important to remember that it is also in the diffuse, aesthetically conveyed affect saturating a video game that the player is worked over. In the following pages, this essay will move from the familiarity of a game filled with recognizable tropes, and move beyond its apparent formulaic dimensions, observing, working through, and contending with resistances in the game to itself as an object that uses its affective dimensions to communicate a political position. In this way, Days Gone becomes a vital text for accessing an anxiety within the current socio-political moment, particularly because it possesses a difficult political perspective that nonetheless should be engaged in a sustained conversation, rather than dismissed.

From a methodological standpoint, my work is also influenced by the work of Joane Morra, whose art historical and visual studies inflected critical theorizations accounts for the "material, personal and political aspects of art" and the "processes that take place in the spaces of artistic cultural and psychoanalytic practices" (UAL). I invoke here the personal and subjectively understood experience of observing, working with, rejection of, and returning to Days Gone, to provoke something unthought about what this game may mean, beyond its apparent generic representations of Americanness. It is necessary to understand "how the personal becomes material" through a resistance to expected readings that make space for the subjective, the responsive, and some of the internal narratives that may inform a personal experience of gameplay (Morra and Talbot 161).

11 How can an expanded understanding of subjective, embodied practices in games research (playing, contemplating, revisiting, working through) inform what constitutes the work of critical game studies? Expanding this conversation to include practicebased research principles of Morra's work-if a bit less squarely psychoanalytic-this essay proposes methodological tools for game studies to harness diversity of thought and to combat rhetorically expected or methodologically pre-programmed thinking. This is in the service of evading ideologically predetermined interpretation, but as a space-clearing gesture toward what conversation an American video game like Days Gone can open up.

\section{Beginning in a Familiar Place}

Days Gone presents itself, on its face, as unreservedly conventional in terms of genre expectations. The game's inciting incident focuses on a biker named Deacon St. John (actor Sam Witwer), who helps his wife, the botanist and research scientist Sarah 
Whitaker (Courtnee Draper), onto a helicopter after she is gravely injured. In the commotion of the panic, we learn in a cut-scene that the helicopter will only take two. So, Deacon chooses to stay behind with his friend Boozer (voiced by Jim Pirri), who has a leg injury and will need assistance to get out. Deacon reluctantly entrusts his wife to the hands of James O'Brien, a fledgling field officer for the FEMA-like "National Emergency Response Organization" (NERO).

Two years later, we meet Deacon again. He is noticeably more haggard and battleworn; together with Boozer, he navigates a post-apocalyptic high desert Pacific Northwest scenario (Figure 2). We learn that Deacon is a drifter and mercenary, who mourns the past and his dead wife, Sarah. Boozer, a former trucker, is his only link to that past, and the only exception to his rigidly outsider existence. By their decorated matching kuttes, a player can see that-before the apocalypse-they were both members of a motorcycle club called the "Mongrels". The two have a zest for killing Freakers, and Deacon channels his bitterness into acts of targeted rage against the infected and those who prey on the weak. Deacon's moody standoffishness is clearly an iteration of a few popular media characters. First, there is Daryl Dixon, an original character on the AMC television show The Walking Dead (2010-), who is also a former biker, wears a similar vest, is a skilled tracker, and carries his iconic crossbow. The second obvious reference is to the character of Jackson "Jax" Teller from the Sons of Anarchy an FX television series (2008-2014) about a California-based outlaw motorcycle club, roughly inspired by the Hells Angels. Both of these figures were popular at the time of the game's release and would borrow from the cache of the existing visual literacy of those series. In addition, the pandemic theme has occurred in innumerable mainstream films that would have been in the popular imaginary, such as 28 Days Later (2002), Dawn of the Dead (2004), I Am Legend (2007), The Crazies (2010), Contagion (2011) and World War Z (2013).

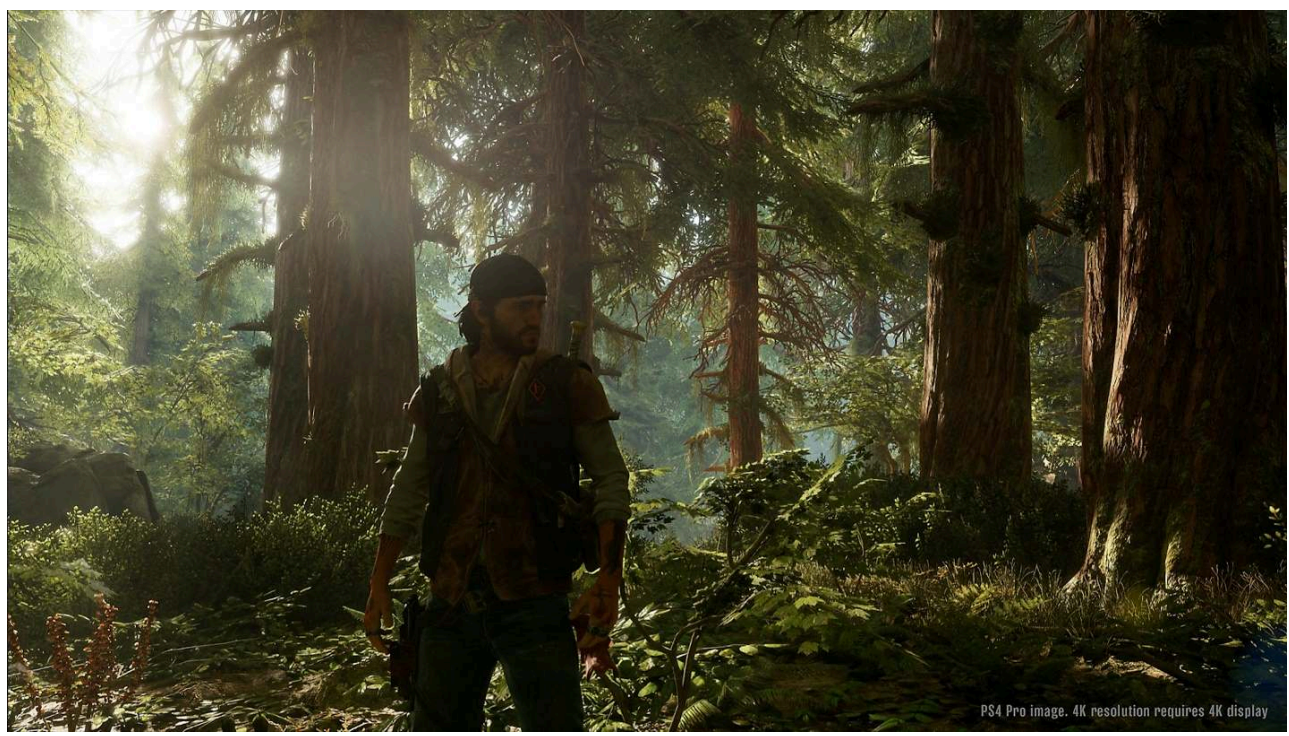

Figure 2.

The game is storyline heavy, with frequent cut-scenes. Through accessing areas on the map, various narratives open up, each of which provides insight into the main character. Gameplay results in the unlocking of stories. That is, this game contains action, but the goals of the action are structured around stories as rewards for successfully completing that action. Deacon is certain of Sarah's death, but discovering O'Brien is alive reignites his curiosity, setting him on a series of exploits to learn the 
truth. A lot of time is spent clearing spaces of Freakers and other threats and opening up new areas on the game's map. As the world of the game unveils itself, and the territory of game space expands, one comes into contact with various camps. Each of these is a thinly veiled representation of an ideological position: the militarized camp (the Deschutes County Militia) represents the impulse toward strongly militaristic hierarchical relations. Copeland's Camp has "martial law" scrawled across its sign and is described by the creative director as possessing a truther, libertarian, antigovernment standpoint which Copeland preaches on his Radio Free Oregon radio show. Another is a work camp with a tinge of the despotic-it is run by a former prison warden named Tucker, and everyone must strictly obey and earn their keep in order to remain. Another embraces rule-of-law in principle (Iron Mike's at Lost Lake). As Deacon, you must build trust with each camp separately, through favors and by bringing in bounties in the form of ears from the infected you have killed. Also you can collect meat, medicinal plants, and mushrooms, all in exchange for supplies.

As for the hostile dystopic scenario, there are the uninfected but dangerous Marauders (Figure 3) and "Rippers" who worship Freakers as the next evolutionary stage of human life, but more interestingly an assortment of infected humans and animals. Freakers are the most basic form of infected, but over the game you learn that they are evolving, too, and there are wide varieties of them. Sometimes, there are complex negotiations of these entities in the space which involves more avoidance than destruction-but mostly, you kill them.

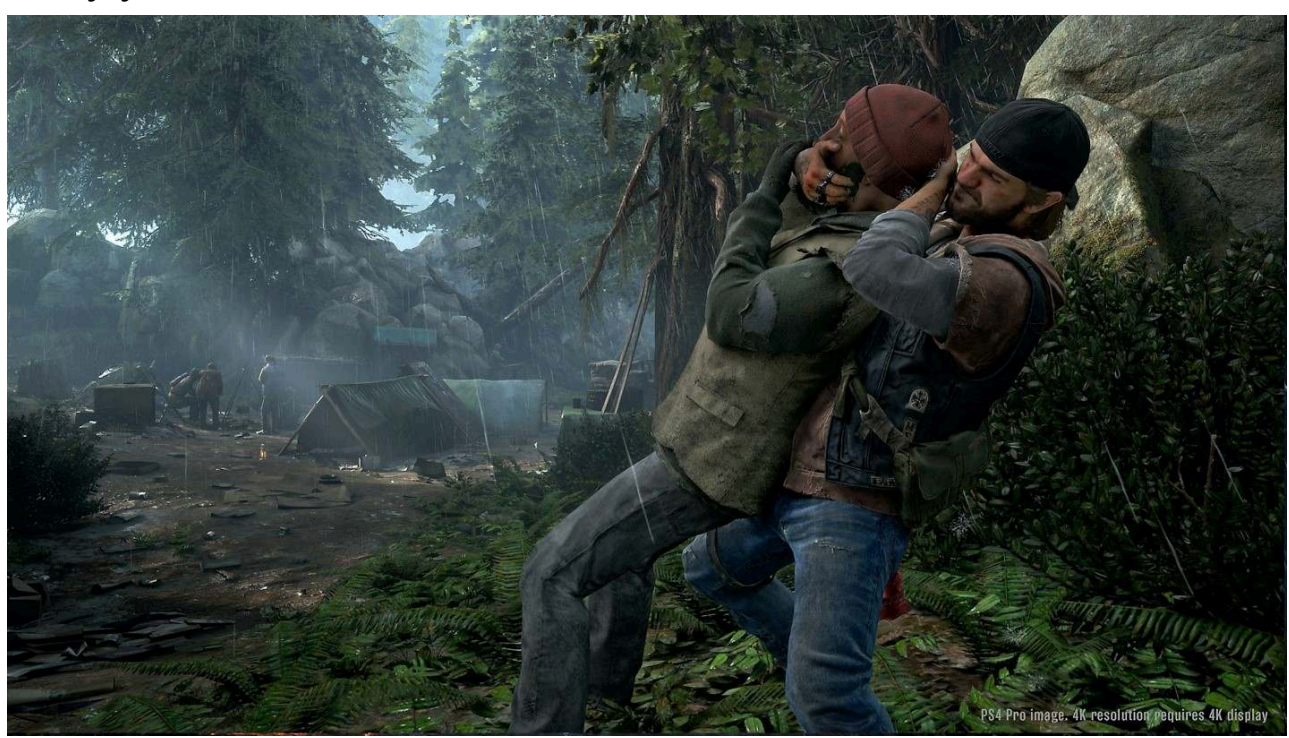

Figure 3.

One might infer from a superficial look at Days Gone that what is offered is merely a layering of video game clichés. Despite its formal beauty, many reviews derided its formulaic dimensions, with leads like: "Days Gone is a lavishly produced, painfully generic PS4 zombie game"; "Days Gone review-a shallow copy of many better openworld action games;" or the more cutting, "Days Gone Is Basically AAA Video Games: The Video Game" (Webster; Hetfeld; Schreier). There is a tragic, brooding, white, male protagonist with lots of weapons. And there are hackneyed cut-scenes, conventional action scenarios, and genetic mutants. One colleague referred to this as a "Walmart" version of The Last of Us-another game of the same zombie dystopia action survival genre, though widely lauded as one of the best games ever made. ${ }^{3}$ This is an apt 
observation about a lower, working-class subject of history invoked by Days Gone-and surely a self-aware creative decision on the designer's part. These elements, in their generic dimensions, initially push me away. But as I observe and engage with the game, I am pulled through its typical packaging, to something affective operational beneath its surface. Days Gone offers an insight into an American perspective whose currency has gained significant traction in domestic politics since the Obama presidency years. This smartly operates on an affective level, while remaining within genre conventions.

\section{Dispossessed Whiteness and Character as Politics}

One may customize Deacon's weapons and motorcycle, but Deacon's person is nonnegotiable. This is telling. In the wake of a video games era of pursuing almost infinitely customizable detail, it is no small thing that this title offers a very specific character and development arc, in which one can only reveal-but never alter-the character's identity. Over a series of playable storylines, players learn that Deacon was once in the Army and did a tour in Afghanistan with the $10^{\text {th }}$ Mountain Division, but was traumatized after an incident of combat in which he was the lone survivor. ${ }^{4}$ His survivalist skills have origins in his Americanness, upbringing, and military past, as well as his status as an enforcer for the Mongrels. Within American popular visual culture, he would be readily recognized as signaling a constructed alterity in the sense of not occupying an economically privileged position. He is someone who is on the fringes of society as an outlaw biker and drifter, and even someone who has served his country, but has not been taken care of by that country in return (Figure 4). In keeping with predominating consumer expectations, Deacon does conform to a highly traditional, normative militarized masculine ideal of resourcefulness, combat readiness, strength, protectiveness toward women and children, as well as emotional hardness. ${ }^{5}$ In this he is also generic.

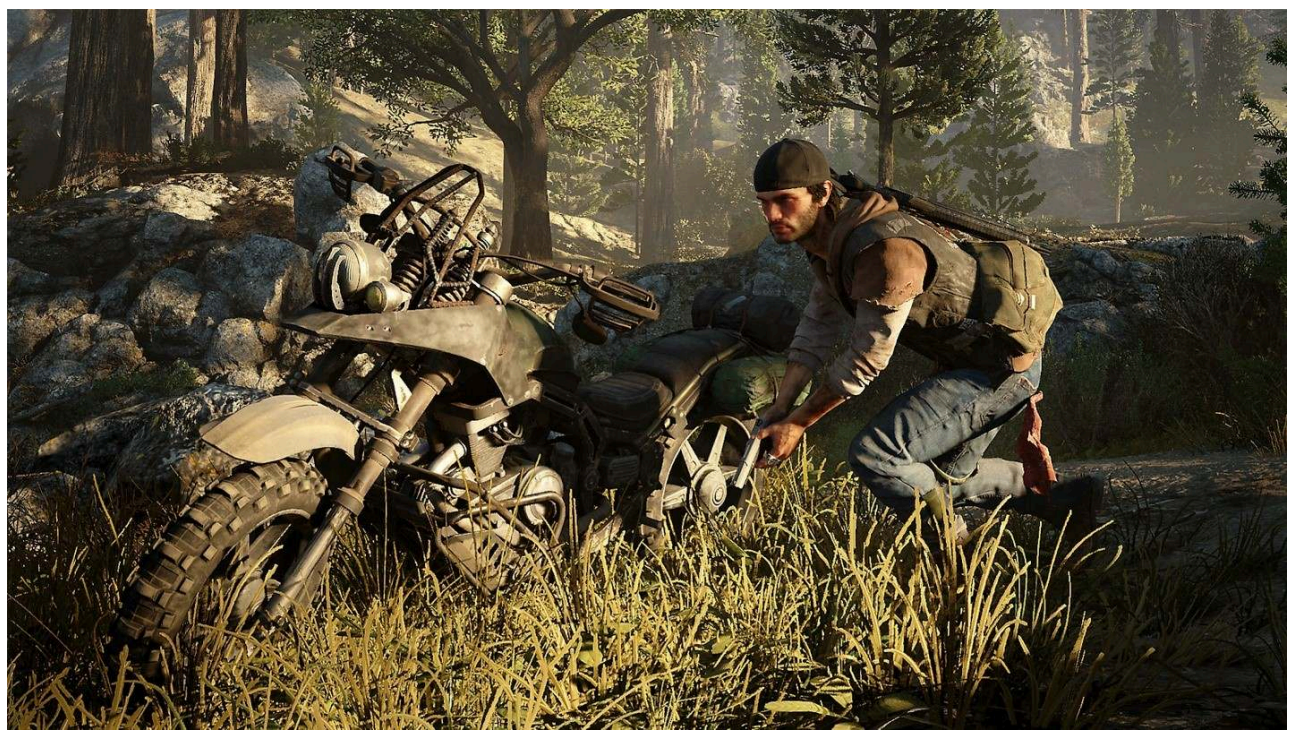

Figure 4.

As I have examined in earlier research, the socio-political and cultural moment in which this sort of narrative would be considered impactful has intensified, rather than dissipated (Murray, On Video Games). Specifically, with the re-election of President Barack Obama in 2012, a strong outpouring of disbelief and anxiety erupted from major 
right-wing public figures like Bill o'Reilly, Donald Trump, Ted Nugent, Ann Coulter, Rush Limbaugh, and others regarding the 'death' of traditional America. Expressed was a strong desire to "take back" the nation and make America great again (Krieg; Horsey). Time has shown, since that research was completed, that this language heralded a strong impulse within the nation, and a mobilization of racialized coding that gave rise to an alt right turn in the Republican Party. Republican politicians mobilized xenophobia and thinly veiled forms of othering to appeal to the malcontent of those feeling something was being lost in the nation. In particular, I pointed to an "aesthetics of ambivalence" in which representations of whiteness are constructed as both normative (i.e., universal) and also as the real other, beset on all sides by hostility.

This white male victimization has been key to the Men's Rights Movement as well as the 2016 Donald Trump presidential campaign (Rosin; Messner; Kimmel). Within the context of a growing polarization between the West and its others, the survivalist scenario suggests fears of being overrun, subjugated, or suffering in global economic restructuring. It is hard not to read the representation of a beleaguered white, normative American as hounded on all sides, given projected demographic shifts that would render whites the "minority" in the near future (Hsu). In the context of this, the scenario of Days Gone takes on strong symbolic terms, and this cannot be fully separated from any analysis of the game. This is embodied in Deacon who, while collaborating with many characters of color throughout the game, is also subject to a symbolic radical otherness in the form of Freakers, who have claimed the nation (Figure 5).

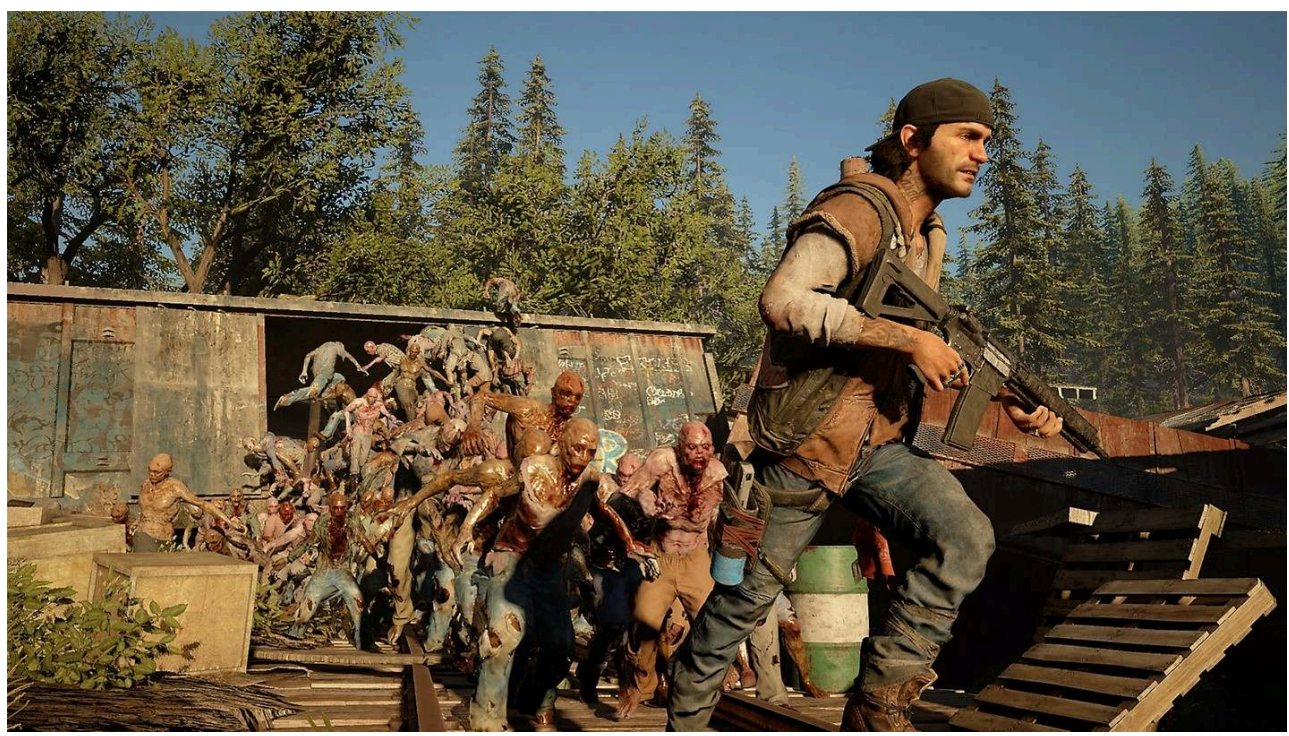

Figure 5.

Deacon is self-consciously calibrated and presented as a character who stands apart from the various perspectives represented in the game. This happens throughout the narrative, through Deacon's annoyance with the extremist conspiracy theory radio Copeland hosts, Radio Free Oregon. Even in name, St. John is configured as a kind of John the Baptist, a hermit in the wilderness, and a harbinger of a new way. However, he is also carefully modulated over a series of unfolding storylines not to be cast in the role of white supremacist or racist. Among the many other examples is a flashback where, during Sarah and Deacon's early courtship, he teases her about a "PC" comment she makes while they are talking about early explorers to the region. He disabuses her 
of her biker stereotypes by pointing out his club's rivalry with racist skinheads, and that a black friend with whom he served in the military is a "patched" member.

Deacon also comes into contact with several characters of color with whom he demonstrates social comfort or even closeness, such as Rikki Patil, a recurring SouthAsian American female character, with whom he and Boozer briefly rode. It is strongly oriented around their usefulness within the context of the apocalypse. There is Addison "Addy" Walker, a black female veterinarian-turned-doctor, who is also Rikki's romantic partner. Derrick Kouri, a captain in the Deschutes County Militia and James Weaver, who is a chemical engineer, are both African American. Arturo Jiminez is a doctor from Mexico, who treats Deacon, and offers the loner sage advice about the value of alliance in times of struggle. All of these characters are presented with a great deal of humanity. The presentation of these supporting characters is significant on a politically affective level because it upends a starkly race-based reading of the libertarian vision as a purely Anglo-American one. Through sustained play, I begin to parse out a political affect within the game that seeks to disrupt the presumption of a generic white male character's intolerance. But this takes some sitting-with and working-through. Deacon is still the core character around whom a struggle for recognition is waged, but the designers have stepped carefully. The particular feelings to which Days Gone affectively give shape operate on a more symbolic level, through the radical otherness presented in the form of the infected.

\section{America Has Died!}

Days Gone presents a disaster in the form of a global pandemic. Carmen Lugo-Lugo and Mary K. Bloodsworth-Lugo have, among many other scholars, drawn attention to the ways in which the 9/11 World Trade Center attacks have been deeply traumatic to the American psyche, and that films like the ones mentioned above express a sense of personal dread and paralyzing feeling of uncertainty and loss of control around the threat of looming disaster. Attending to films that deal with the global pandemic, such as Contagion and World War Z, they discuss fears of societal breakdown and terrorism embodied in the germ or the zombie. In their analysis, they connect Bush-era rhetoric around a "war on terror" to the imaging of white men terrorized ultimately by the global flow of bodies and their inability to protect their families from it all (Bloodsworth-Lugo and Lugo-Lugo). Contagion (like innumerable other panic films) suggests that the pandemic can quickly topple order and create fear and chaos, mistrust, ignorance, and skepticism around the government's ability to fix things. In World War Z, the male protagonist (played by Brad Pitt) is a UN worker who is resourceful and trained, and he is called in by the UN Secretary General to investigate potential solutions to a viral zombie outbreak. The film strongly features themes around survivalism and images the near-extinction of humanity. Like many of these filmic scenarios, players engage the game space as a white male protagonist who-at least in the beginning of the game-has been marked as someone unable to protect his wife from the world. As the two authors explain about such films: "Viewers are told that the apocalypse happens to whites; it is up to white men to fight it; white men must protect their families; and the apocalypse can be managed or overcome by these men" (Bloodsworth-Lugo and Lugo-Lugo 173). Likewise, players of Days Gone are cast in the role of a white male (reluctant) hero taking charge and tipping the balance toward the 
reestablishment of order. Deacon is repeatedly tasked with using his skills as a drifter, bounty hunter, and mercenary to right wrongs, thin the Freaker population, and solve problems for various communities-though he largely holds himself apart. There is the killing first of individual Freakers, then small groups, and finally great "Hordes" of Freakers in the hundreds (Figure 6). It is a practice of accustoming one's self to fear and learning to control it enough to survive and ultimately dominate the situation.

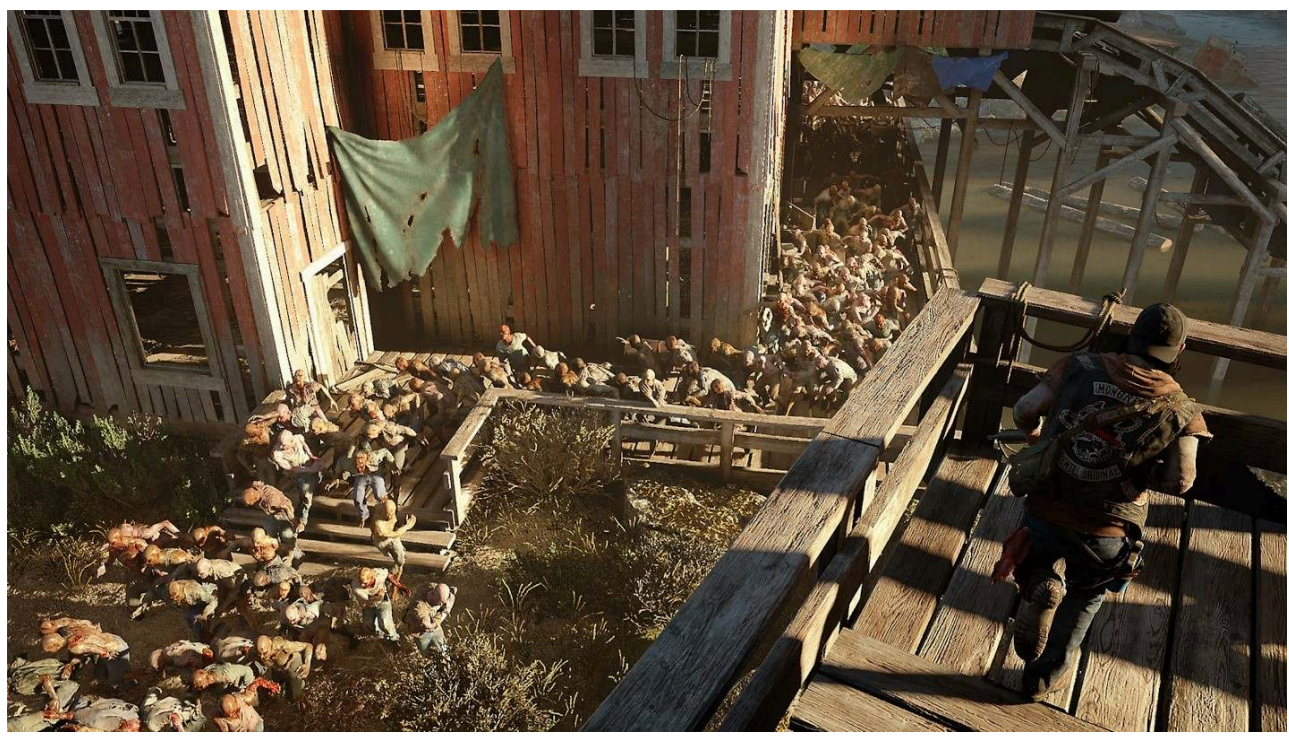

Figure 6.

The procedural nature of gameplay greatly contributes to the overall survivalist / prepper outlook due to its focus on gathering key supplies, crafting, and harvesting of things like meat, mushrooms, and plants. One spends a great deal of time repairing one's motorcycle, filling up its tank with fuel found along the route, and recycling scrap and car parts for tools and weapons. Resilience and resourcefulness are strong messages of the game. Along with this comes the fundamental idea that there is something that can be done, gains that can be made, and that individual human endeavor can have a meaningful impact. There is an overt attention to behaviorally adjusting to panic. This is emblematized by the cover art, which depicts Deacon reclining against his customized motorcycle and gazing out at the viewer, even though a Horde approaches from the entire horizon, and the bodies of the dead are strewn before him. It is evident, as well, in the game's focus on the forty instances of Hordekilling expected, in which the frantic nature of the undertaking often requires grasping one's own feelings tightly under control. The affective intensity of the video game modulates between the notions of killing and surviving. Mostly, it says: survive, survive, survive. There is an underlying statement about those best suited to survive: essentially the gun fanatics, traumatized former soldiers, and the bad people, who will do anything to anybody. And there are those with essential skills, like mechanics and construction workers; basically, working-class men and women who keep civilization going, but are ultimately exploited and undervalued.

Considering the game in light of 9/11 makes sense, particularly given Deacon's having served in the military and seen active duty in Afghanistan. As character development, it gestures to a generation of young men whose emotional response to the traumatic event was to enlist and participate in the so-called 'War on Terror.' The game, however, is also-and perhaps more precisely-a Trump-era game. It conforms, in many ways, to 
a conversation taking shape around the disorienting shifting dynamics in the political, social, and economic life of the nation. According to an analysis of his formal electoral speeches, published in the British Journal of Sociology, researchers found that Trump:

capitalized on and appealed to workers' desire to assert what they believe is their rightful place in the national pecking order. Trump achieved this by (1) emphatically describing workers as hard-working Americans who are victims of globalization; (2) voicing their concerns about 'people above' (professionals, the rich, and politicians); (3) drawing strong moral boundaries toward undocumented immigrants, refugees, and Muslims; (4) presenting African Americans and (legal) Hispanic Americans as workers who also deserve jobs; and (5) stressing the role of working-class men as protectors of women and LGBTQ people. Many of these workers think of themselves as society's invisible and under-recognized 'backbone,' who keep the American economy going, yet experience a recognition gap. They believe they 'deserve better' and ache to see the country recognize their value and contributions. During the 2016 presidential election, many of these workers rose in protest and anger to follow a man who promised them what they believed was their due after too many years of enduring abuse in silence. (Lamont et al. 154)

As they explained, Trump blamed globalization for having eroded their social position as working people in the national pecking order and pointed to the ways in which he separated himself from politicians through his identification as a businessman who would advocate for the working man, while scapegoating undocumented immigrants, Syrian refugees, and Muslims as corrosive outsiders. The anti-globalization sentiments, increased nationalism, and ultimately the galvanization of what some have called the "New Discontents," have reshaped politics in the United States under Trump (Stiglitz). ${ }^{6}$

These rhetorical positions are evident in the symbolic arrangement of the game, which strongly features characters who are apocalypse-hardened, largely working-class Americans of various identities, who struggle against an overwhelming incursion. For example, in a short sequence called "Tail the Horde," in a storyline called Flow Like Buried Rivers, Deacon shows a settlement leader named Iron Mike a stream of thousands of Freakers as they pour into the region from California, and "not a goddam thing we can do to stop 'em." Deacon hatches a plan to destroy an entrance to a horde cave, as a way to discourage them from stopping there to hibernate and reduce the overall population. The language around the bodies that move north from California seems to invoke the kinds of xenophobic rhetoric around the US/Mexico border, which were whipped up during the presidential election by Trump, particularly in reference to the Central American refugees seeking asylum and the resettlement of Syrian refugees. It was galvanized in his allegations of a coming crime wave and Mexicans in general as criminals, drug dealers, and rapists, with his presented solutions to deport masses of immigrants and build a border wall (McGreal). The flow can also be read in terms of global flows of bodies, capital, and information that result from international global economic conditions that create demand for ever cheaper labor pools-with which American workers cannot compete. This interpretation is not left up to conjecture: in a later part of the game called "Checking the Turbines," Deacon and an ally, Rikki, discuss a destroyed bridge in the distance. Deacon explains that it was done intentionally to keep out the hordes. Rikki responds, asking whether it was hordes of refugees or hordes of freaks that were being kept out. Deacon responds that, knowing Copeland, "probably both." In these rhetorical slippages between fiction and political realities, the game gains potency as a document of a particularly fraught political moment. 


\section{Games and Politics}

Days Gone is a difficult object on account of its difficult politics. In its affective intensities, it conveys conspiracy-theory logics and anti-government sentiments, displays nihilism, and treads into separatism, even while there are some alliances modeled. Released in late 2019, this video game entered into a context marked by a spirited public discussion about the presence of politics in video games. The primary debate was around whether games should contain overtly political topics; an extension of the charge that games are being taken over by social justice warriors who wish to inject their politics into games. Then, there was the pattern of game companies denying that politics exists within their games, despite overt political references, such as the representation of a modern-day civil war, or the resurgence of white supremacy groups, or a militia stand-off against law enforcement. Terry Spier, creative director of Red Storm Entertainment, which delivered Tom Clancy's The Division 2, claimed the narrative which features a Washington D.C.-based narrative of a civil war in which the people take up arms against a corrupt government is "definitely not making any political statements" (Hall; Alexandra). Detroit: Become Human (Quantic Dream, 2018) undeniably references the civil rights movement and specifically Martin Luther King, Jr., via androids-but is it only "really about androids" as director David Cage claims?7 (Alexandra) Games journalists pushed back. Edwin Evans-Thirlwell blasted "technothriller" genre innovator Tom Clancy's "noxious" influence on the medium, whose branding of political thriller games "quietly advocate hawkish attitudes and philosophies while trying to lose the player in their lethal machinery, in the smooth interlocking components and command structures" (Evans-Thirlwell). Games journalist Colin Campbell unpacked the issue of the refusal to discuss the politics in their games, concluding that companies want to "garner publicity and a sense of cultural relevance but ... avoid the challenge and expense of controversy" (Campbell).

Breaking with the herd, Creative director of Days Gone, John Garvin spoke openly about political viewpoints being expressed within the game:

'There are a multitude of viewpoints in Days Gone. You've only had a chance to experience two of them,' he says. He points to Copeland, a Days Gone NPC [nonplayer-character] who runs one of post-apocalyptic Oregon's many settlements, and who talks frequently about what the U.S. Constitution means to him (a lot). 'Certainly Copeland with his truther theories, and if you're playing the game, you might hear one of his Radio Free Oregon broadcasts. Copeland espouses this kind of libertarian viewpoint that's anti-government, as well as conspiracy theories and whatnot.' (Bailey)

The game does feel fundamentally libertarian, and according to an interview with US Gamer, Garvin described his mother as a founding member of the Citizen's Committee for the Right to Keep and Bear Arms, a group whose ideas he does not share, but which exposed him to the "very, very, very right wing sort of conspiracy theorist, hate the federal government, blah, blah, blah," that exists in Oregon (Bailey). On this, his interviewer observed:

Garvin isn't wrong about Oregon being a hotbed for right wing militias. Bend Studio itself is based in the town of Bend, Oregon, which sits about 250 miles away from the Malheur National Wildlife Refuge-the sight of the occupation by Ammon Bundy and his gang in early 2016. It was the opening salvo in what would be 
probably the wildest and most depressing year for politics in recent memory. It's against this sort of backdrop that Days Gone establishes its setting. (Bailey) conspiracy theories circulating since the 1980s that FEMA will round up U.S. citizens under the pretense of martial law, and detain them in concentration camps (Keller). Early on in the novel coronavirus outbreak, similar false stories began circulating on Facebook indicating that Director Pete Gaynor had recommended martial law and Twitter posts falsely claiming "dormant plans for martial law and widespread FEMA detention camps in America" (Lajka). As an acronym, NERO implies the historical corrupt Roman emperor and known persecutor of Christians, whose despotism and cruelty destabilized the Roman empire. NERO is cast as a powerful entity directing teams of hazmat-suited agents to engage in Freaker research, while ignoring the plight of those humans left behind. Completed well before the COVID-19 global pandemic, the game undoubtedly takes on new meanings with the realities of sheltering-in-place and fears of global economic catastrophe. While Days Gone feels very much like a Trump-era game, right down to the yearning expressed in its title for earlier and better times, the pandemic element cannot help but prick the player anew.

A key part of the narrative ties Sarah specifically to the pandemic. She feels responsible for the apocalypse-and can be construed within the narrative as having played at least a critical role. David Gorman, a research intern at the Cloverdale research facility where Sarah works, "wanted to be the next Edward Snowden" and expose the "Evil Empire" for their top-secret nefarious research. She explains that she ignored his warnings as paranoia, leading him to steal a sample, with the intention of exposing Cloverdale to the press at a green Expo in Portland. But instead, he exposes the people of the conference to the infection and, upon their departures to their respective homes, they spread the Freaker virus, causing 2.5 billion deaths within a week. She is cast, in this instance, as the lone tragic Oppenheimer figure who inadvertently opened Pandora's box, and who is driven to find a scientific solution to the problem. The syrupy-sweet flashbacks of better days gone by present Sarah as bright, literally glowing in her visage and intelligence, if a bit naïve about how her research is being used. Post-pandemic Sarah, notably less incandescent, bears the palpable burden of knowing her work greased the rails for the apocalypse. That is to say, one of the largest revelations of the game is its disclosure of Sarah's culpability. This can be read as a blunt critique of gender-based social roles and the annihilative potential of science in the hands of women. However, my reading is one that is more tinged by the persisting societal problem of women as the bearers of reproductive capacities as a cornerstone of society. In this instance, the perverse scientific tampering with the genomic has resulted in monstrous children-which Sarah holds herself responsible for, though she 
was unaware of Cloverdale's aims at the time. In this, the game presents Sarah somewhat sympathetically as a tragic figure who was used as a tool of the state, in negligence of the people. It ultimately reads strongly as cynical and distrustful of government and scientific industry, which has misused the reproductive potentials of Sarah's research.

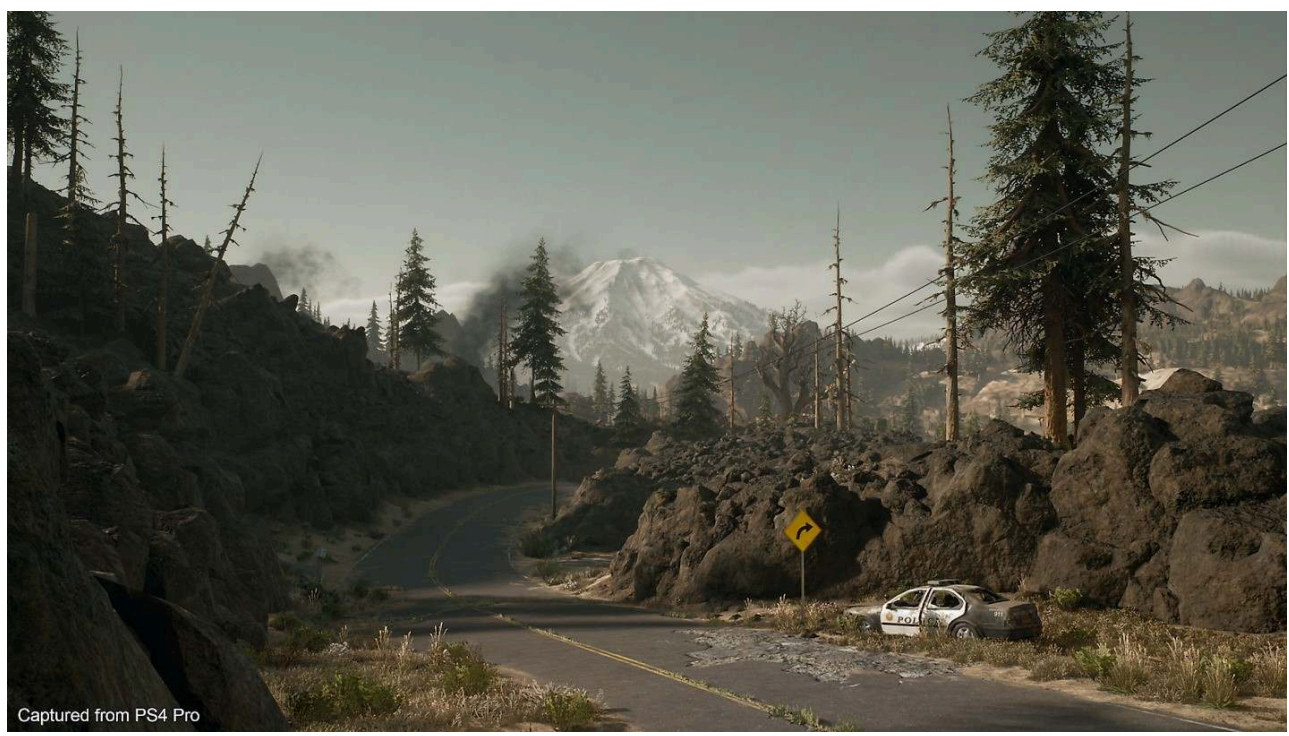

Figure 7.

\section{Landscape As Political Feeling}

I propose here a kind of "background" reading, in which the focus moves from the characters themselves to the spaces within which they move. The intensely detailed beauty and variation of the terrain, with its fickle weather patterns and the Cascades in the distance, all contribute to the political feeling of the Days Gone (Figure 7). It is more treacherous at night than in the day. The foliage sways gently. The simulated sunlight and colors of the land accurately capture the distinctive feeling of the Pacific Northwest (Figure 8). Deacon can hide by crouching in dense bushes. The shifting climate shapes the behavior of the living things within the gamespace, infected and otherwise. Weather patterns and time of day impact horde movements and activity; they are more active at night, and in rains or snow. In the day, fewer Freakers stray from their nests and caves. Paying careful attention to the environment has a direct impact on successfully navigating the hostile space. The land opens out to you as a player in exhilarating ways, but it is interrupted by unwanted elements: marauders, Hordes, etc., that short circuit the pleasure of flows. Uninterrupted flow within the land is dependent upon clearing threats. Atmosphere is established through a languid "folk Americana" sound, as described by Nathan Whitehead, composer of the Days Gone original score (Whitehead). It aesthetically cues the player to the ambient shared feeling of the game. This shared feeling is ideologically powerful, though ephemeral:

Affect shapes the surface and very being of subjects and objects as they come into contact with each other. Affect is not inherently counter-discursive or progressive; often, shared feelings tend to reinforce individual, regressive, and normative ideas. But affect also circulates and is subject to history and change. Affect has the possibility of forming counterpublics around the cultural expression of underrepresented feelings. (Anable xviii) 


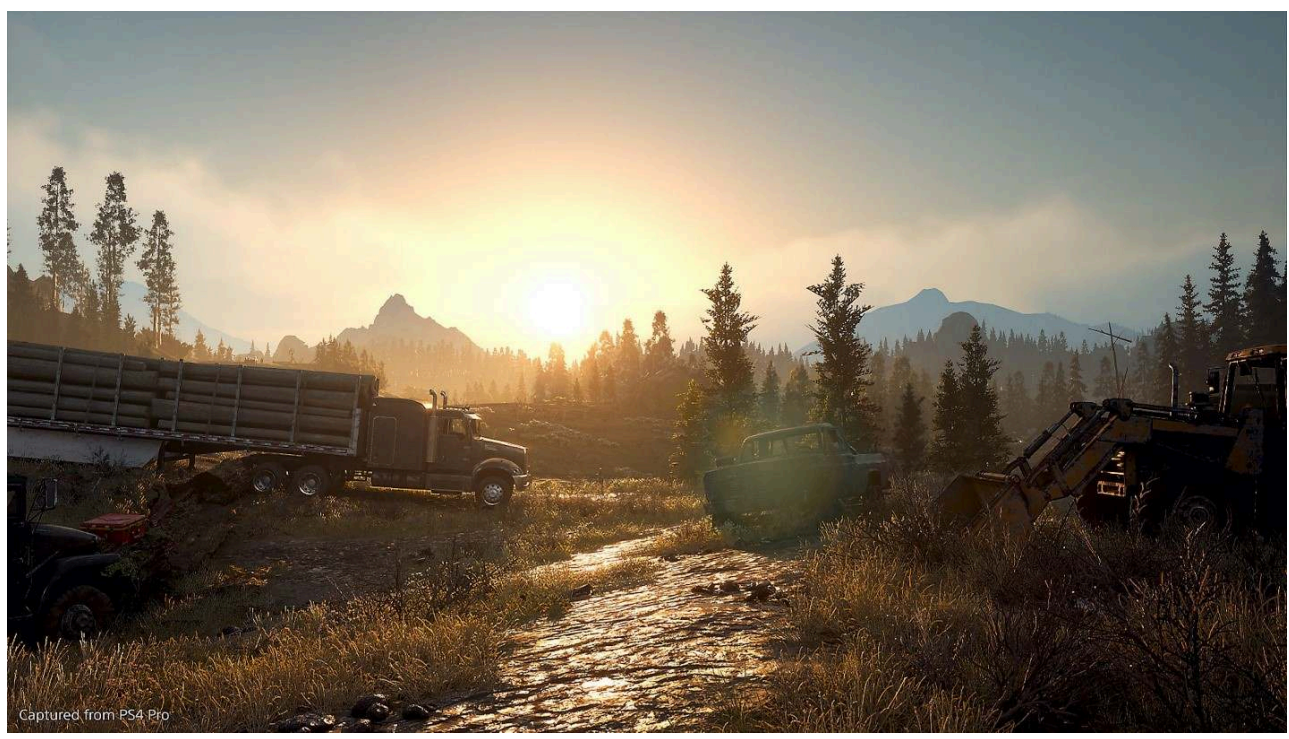

Figure 8.

Days Gone affectively reinforces a particular vision of a particular world, one that places individuals in perpetual conflict with each other, out of sheer cruelty or competition for scarce resources, within a hostile and unforgiving landscape. It affectively communicates "underrepresented feelings" through its spatial frictions. The Freakers and humans are competing for dominance. One must kill many large hordes to regain territory. But if you pay attention to the landscape, other melodramas unfold, sometimes even without your intervention. I've seen Freakers attack animals, animals attack Freakers, infected wolves (Runners) attack anyone; giant infected bears (called Ragers) rampage about as well. After some time, there are also infected birds (Criers), who strike from above, and whose nests you need to bomb with Molotov cocktails. The various entities fight each other often; they are not necessarily explicitly focused on you as the player. You can also lure enemies to fight other unwitting antagonists. For example, a horde can be lured to strategically destroy all inhabitants of an ambush camp. Conversely, you can channel Freakers to an ambush camp for marauders to destroy the majority of the Horde, effectively putting them to work for you.

The landscape is strongly configured as an American wilderness which has been overrun and must be taken back. In many instances, the land is taken back by explosive fire; in one case, by being cleansed through literally washing away all the scum (in this case in the form of Rippers) by destroying a reservoir. Interestingly, the Hordes (consisting of groups of hundreds of Freakers) become a part of the environs over time. The most intense gameplay involves Horde killing, of which there are forty throughout the game, of various sizes. Horde killing is not easy, affronting the player like a panic at first. One tends to resort to fleeing, firing indiscriminately, and unstrategically lobbing explosives. But with repeated exposure to the challenge, one learns to find high ground where they cannot easily find you, then strategically draw them into a series of prearranged traps. Then lob the incendiary bottles and take out the rest with your guns. Panic and confusion lead to eventual tactical innovation, and ultimately, to control. As one becomes more accustomed to contending with the masses of infected and more strategically attending to them, they become like flows in the background. The anxiety narrative is not my anxiety; but I feel it through the aesthetically conveyed affect. 


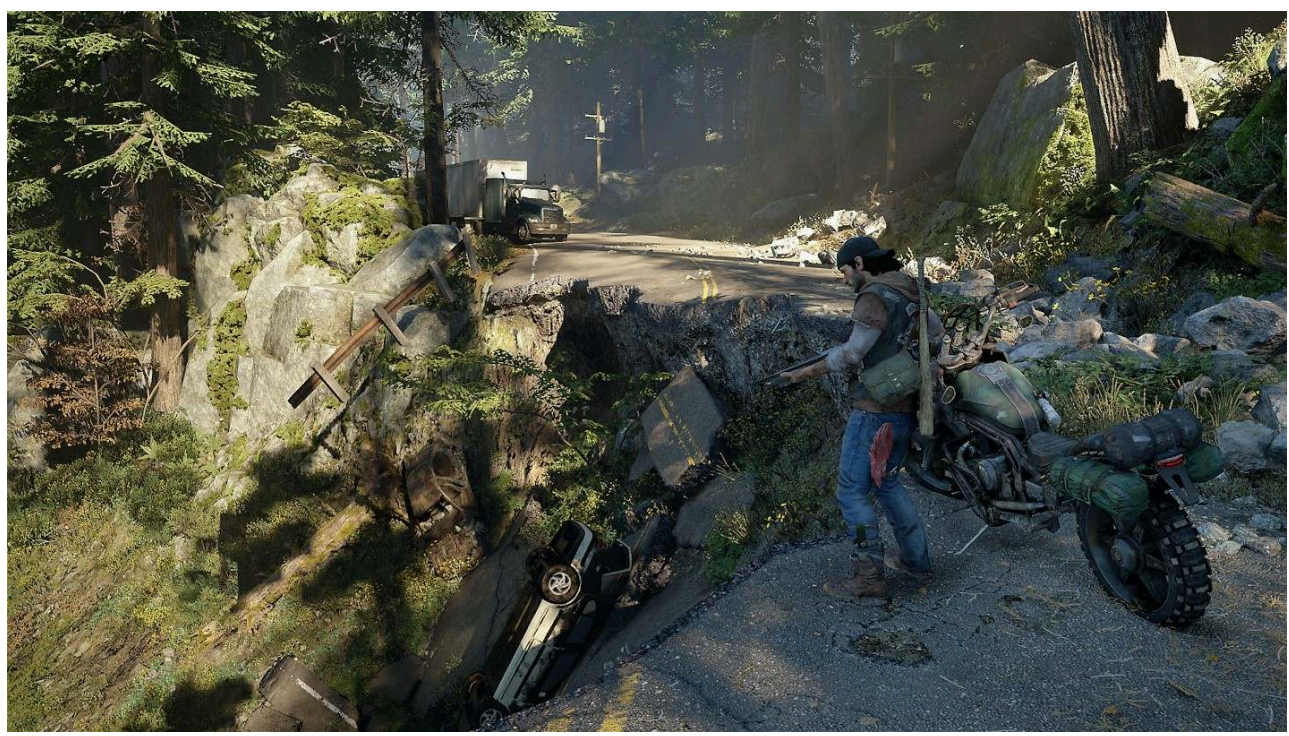

Figure 9.

The task of this cleansing is put in the hands of a specific kind of person (a cipher for populist thinking) and its necessity is conveyed in large part through the land that is a resource that should be in one group's hands and not in another's. The detritus of a past, consumer-based civilization is everywhere, illustrating the recalibrated value of things according to usefulness in the new order (Figure 9). The game consists of many series of integrated systems in which natural processes become tied to the behaviors of animals on the land, of the infected, and people. Those behaviors impact player actions, opportunities, and outcomes within the gamespace. Successful navigation of the space relies to a great extent on one's ability to keep track of the changing light and the weather, and to observe the land for its traps and advantages. There is a palpable sense of awe for the land, in the grandeur with which it is aesthetically conveyed.

The landscape of Days Gone is perhaps its most original component, in terms of the careful attention paid to photorealistic detail, and the centrality of the natural elements for specific outcomes of gameplay. The very space of the game, through its representation of a sprawling and majestic landscape, rich with resources for gathering, in the brisk, grand embodiment of the Pacific Northwest, promises an abundance and a "reset" of the U.S. to a fantasy of off-grid type living and self-reliance in a new Eden. From an art historical and visual studies perspective, one can also understand it in relation to a long history of cultivating political feeling through landscape painting. The whole scenario of the game recalls, for example, The Course of Empire (1833-1836) by Hudson River School artist Thomas Cole, a renown suite of five landscape paintings which allegorized the social and political theories around the rise and fall of civilizations. It is, in a way, an early American masterwork of dystopian ruin. This series begins with the land untouched (The Savage State), then moves through The Arcadian or Pastoral State, The Consummation of Empire, Destruction, and Desolation. These five works detail a scathing vision of the emergence, glory, and collapse of a decadent civilization, which eventually succumbs to violence, destruction, and the elements. Moving about the game space of Days Gone, a player absorbs a sense of the severe beauty of the land, and the detritus of an empire in ruins and slowly being reclaimed by nature. While cynical, this vision of inevitable doom is blissfully distant from international global trade agreements, the complexities of labor outsourcing, or foreign 
policy. Playing within these landscapes for an extended duration, one gathers a particular affective sense in relation to the game world-but also to a larger political affective intensity that exists beyond the game, in the lived world.

The affective charge of Days Gone rests in the collective force of an emergent feeling, albeit not my own feeling, yet it remains real and widespread within the nation. If these gatherings of feeling can, in this case, give rise to an expression of underrepresented affects, this game is in fact a manifestation of an underrepresented viewpoint. This is to be differentiated from lacking diversity in representation, which it does not. The affective force of that political feeling has actually shaped the U.S. landscape through the election and political turn. Should we not pay attention to this, even though it may push us out as unintended recipients of its intensities? In playing Days Gone, the game becomes a cultural manifestation of that thing which was felt but could not be fully uttered at the time. It certainly captures it much better than the punditry, in both the far right and left-leaning U.S. media, which largely failed to predict or even illuminate the gathering political feeling that would follow.

\section{Conclusion: What This Game Proposes}

Days Gone carries a strong message of self-reliance, and while separating itself from a conspiracy narrative per se, it does contain elements of deep distrust in government that are fundamentally libertarian in terms of a message of sovereignty and individualism free from authoritarian or governmental interference. In this and a myriad of other ways, this story largely conforms to the Western genre-simply without the trappings of cowboy hats, saloons, and horses. Deacon, the outlaw, is largely unwilling to concede his individuality to permanently join one of the wilderness encampments. Garvin explained: "When the federal government is telling everybody to go to these refugee camps, Deacon and his friends are saying, 'Hell no. I'm not doing what you say. That's a death trap. It's suicide. We're not doing that.' The fact that they're rebels and the fact that they flout the law I think plays into their ability to survive" (Bailey). With its sublime American landscape, combined with an aesthetically conveyed political affect of suspicion toward government and too much technological advancement, Days Gone engages with the most foundational of U.S. mythologies.

At the same time, Days Gone offers something more, an insight in its aesthetic durational and spatial experience that points to an intangible gathering political feeling of its own cultural moment. Anable writes that, "The intersection of aesthetics and affect in these games gives us access to the ways the senses make meaning through cultural objects, like games, beyond the scope (and the scopic limits) of representation. This intersection also moves us beyond a tendency in game studies to artificially separate aesthetics from meaning making" (129). The meaning-making of the game rests ultimately in its aesthetic encounter, which concentrates an affective experience of the wish to take things back to a greatness defined by a rugged-individualist connection to monumental land, and the work of one's own hands, unencumbered by the complexities of too much connectedness. It also proposes a host of ideas around the embrace of self-reliance, libertarianism, and more generalized conservatism, funneled through a conventional white, square-jawed, male anti-hero who satisfies the generic demands of purchasing customers. 
Sitting with this difficult object is a source of much emotional fatigue in terms of sustaining myself in a mindset that is not my own. It proposes a look into a kind of Americanness that is incredibly resonant-not with my own experience, but with the unfolding of an American turn toward the nationalistic, toward the inward-focusedand which promulgates a series of narratives about the besieged working man who has been forgotten. It exists in the very form of the game, through its rendering of a landscape into a particular vision of American grandeur, which points to old forms of ideological image management. Remnants of the old expansionist feelings are still there (Figure 10). One is fundamentally presented as a man alone on a motorcycle, with a large region extending its territories to you within the context of a series of necessary traversals. This ties to a significant research direction in video game studies and the postcolonial; however, here I want to be clear that I'm not signaling this game as uniquely worse than any other one whose missions are organized around exploring territories and appropriating resources, with new areas unlocking once those goals are met (Magnet; Höglund; Lammes, Sybille; Dooghan; Ford; Mukherjee; Murray, "Landscapes of Empire in Metal Gear Solid V"). However, Days Gone, in its presentation of American vistas, organizes them into a worldview that makes certain claims about nature as the rightful domain of humans, and all that is contained within it-the inalienable right to that land. Players move about in the ruins of America, scavenging and crafting a new nation.

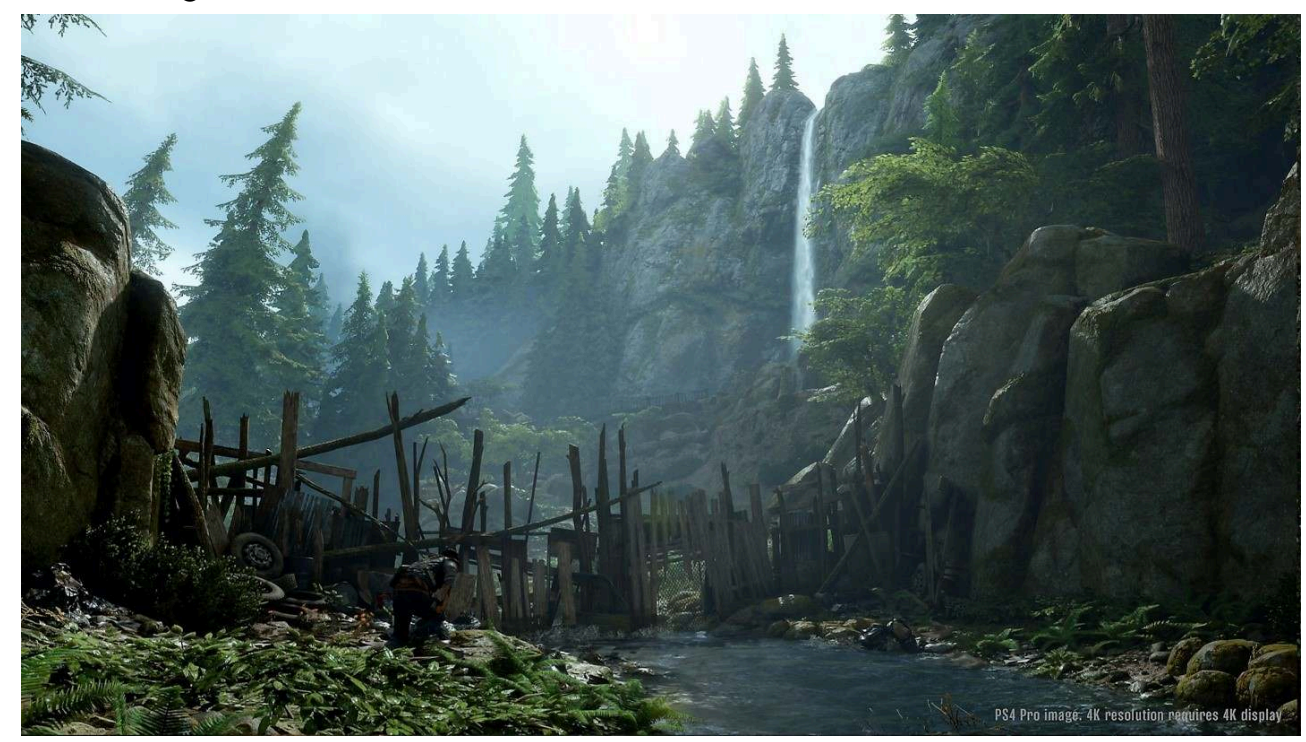

Figure 10.

If it is true, as game designer Anna Anthropy believes, that video games are good at "forcing the player to inhabit a political ideology," then Days Gone becomes useful not as a literal political perspective, but as an object of concentrated political intensity of feeling (Anthropy 122). The critical import of Days Gone lies in its access to an affective intensity gathering in the United States, something that neither the liberal news media has until now been able to illuminate, nor Fox News eloquently articulates. This game openly resists the modeling of a "PC" tolerance, a "politics of culture" as critics of the liberal academy have argued, while also including many women and people of colorbut all of whom operate within a relatively narrow continuum of a strongly populist narrative. I am an American, and the legacy of this political unfolding is as much mine as any other American's. The presence of politics in games is an important point of 
interest, but there is slippage in the critique of game companies that fails to differentiate between the presence of direct political messaging and admitting games may possess political perspective and affect. For me, when engaged with the "political," most games are actually only trafficking in politically triggering scenarios, likely exploiting them for their ability to draw attention. What is revealed from my exposure to the politically affective intensities of Days Gone is an address of an unutterable narrative that might not be the right or true story, but is still deeply felt by the masses -many of whom, incidentally, might fall into Hillary Clinton's "basket of deplorables" (Montanaro). But, wandering for long periods within the spaces of Days Gone, one gains access to an affective intensity of political feeling that has unfolded within the United States in the way it has. As the game shows us, the problems we face on the broken road are mostly within ourselves.

\section{BIBLIOGRAPHY}

Ahmed, Sara. "Happy Objects." The Affect Theory Reader, edited by Melissa Gregg and Gregory J. Seigworth, Duke UP, 2010, pp. 29-51.

-----. "Multiculturalism and the Promise of Happiness." New Formations, vol. 63, 2008, pp. 121-37. Alexandra, Heather. “The Division 2 Is Political, Despite What Its Developers Say.” Kotaku, 12 June 2018, https://kotaku.com/the-division-2-is-political-despite-what-its-developer-1826776710. Accessed 15 Feb. 2021.

Anable, Aubrey. Playing with Feelings: Video Games and Affect. U of Minnesota P, 2018.

Anthropy, Anna. Rise of the Videogame Zinesters: How Freaks, Normals, Amateurs, Artists, Dreamers, Dropouts, Queers, Housewives, and People like You Are Taking Back an Art Form. Seven Stories Press, 2012.

Bailey, Kat. “FEMA, Militias and Motorcycle Gangs: Days Gone's Apocalyptic Politics.” USgamer, 6 Mar. 2019, https://www.usgamer.net/articles/days-gone-interview. Accessed 15 Feb. 2021.

Bend Studio. Days Gone. 2019. bendstudio.com, https://bendstudio.com/games/days-gone/. Accessed 20 Feb. 2021.

Bloodsworth-Lugo, Mary. K., and Carmen R. Lugo-Lugo. “9/11 End-of-Days Hollywood.” Projecting 9/11: Race, Gender, and Citizenship in Recent Hollywood Films, Rowman and Littlefield, 2015, pp. 157-76.

Campbell, Colin. "Why Are Game Companies so Afraid of the Politics in Their Games?" Polygon, 20 June 2018, https://www.polygon.com/2018/6/20/17480666/video-games-companies-lyingpolitics. Accessed 15 Feb. 2021.

Chess, Shira. Ready Player Two: Women Gamers and Designed Identity. U of Minnesota P, 2017.

Dooghan, Daniel. "Digital Conquerors: Minecraft and the Apologetics of Neoliberalism." Games and Culture, June 2016, pp.67-86.

Doyle, Jennifer. Hold It Against Me: Difficulty and Emotion in Contemporary Art. Duke UP, 2013. 
Evans-Thirlwell, Edwin. "If Ubisoft Wants to Cling on to Clancy, It's Time to Talk Politics." Eurogamer, 22 June 2018, https://www.eurogamer.net/amp/2018-06-20-the-oppressive-afterlifeof-tom-clancy?_ttwitter_impression=true. Accessed 20 Jan. 2021.

Everett, Anna, et al. "Race, Space, and Digital Games: An Interview with Anna Everett." Media Fields Journal, vol. 8, 2014, pp. 1-11.

Ford, Dom. “'EXplore, EXpand, EXploit, EXterminate': Affective Writing of Postcolonial History and Education in Civilization V." Game Studies, vol. 16, no. 2, Dec. 2016, http://gamestudies.org/ 1602/articles/ford. Accessed 10 Jan. 2021.

Gould, Deborah, et al. "Affect and Activism: An Interview with Deborah Gould." DisClosure: A Journal of Social Theory, vol. 28, no. 8, 2019, pp. 95-108.

---. "On Affect and Protest." On Affect and Protest, Routledge, 2010, pp. 18-44.

Gray, Kishonna L., and David J. Leonard, editors. Woke Gaming: Digital Challenges to Oppression and Social Injustice. U of Washington P, 2018.

Hall, Charlie. “Tom Clancy's The Division 2 'Is Not Making Any Political Statements.”' Polygon, 12 June 2018, https://www.polygon.com/e3/2018/6/12/17451688/the-division-2-is-not-makingany-political-statements. Accessed 10 Jan. 2021.

Hetfeld, Malindy. "Days Gone Review - a Shallow Copy of Many Better Open-World Action Games." Eurogamer, 25 Apr. 2019, https://www.eurogamer.net/articles/2019-04-25-days-gone-review-ashallow-copy-of-many-better-open-world-action-games. Accessed 15 Feb. 2021.

Höglund, Johan. "Electronic Empire: Orientalism Revisited in the Military Shooter." Game Studies, vol. 8, no. 1, Sept. 2008, http://gamestudies.org/0801/articles/hoeglund. Accessed 15 Jan. 2021.

Horsey, David. "Obama Win Brings the Great Right Wing Freak-out of 2012." The Baltimore Sun, 13 Nov. 2012, http://articles.baltimoresun.com/2012-11-13/news/bs-ed-horseygop-20121113_1_corporate-welfare-americans-election-results. Accessed 20 Feb. 2021.

Hsu, Hua. "The End of White America?" The Atlantic, Feb. 2009. The Atlantic, http:// www.theatlantic.com/magazine/archive/2009/01/the-end-of-white-america/307208/. Accessed 20 Feb. 2021.

Keller, Larry. "Fear of FEMA.” Southern Poverty Law Center, 2 Mar. 2010. www.splcenter.org, https:// www.splcenter.org/fighting-hate/intelligence-report/2010/fear-fema. Accessed 10 Jan. 2021.

Kimmel, Michael. Angry White Men: American Masculinity at the End of an Era. Nation Books, 2017.

Kline, Stephen, et al. Digital Play: The Interaction of Technology, Culture, and Marketing. McGillQueen's UP, 2003.

Krieg, Gregory J. "Freaking Out: The Best of the Worst Responses to Obama's Win." ABC News, 8 Nov. 2012, http://abcnews.go.com/blogs/politics/2012/11/freaking-out-the-best-of-the-worstresponses-to-obamas-win/. Accessed 15 Feb. 2021.

Lajka, Arijeta. "FEMA Has Not Proposed Martial Law to Contain Virus Outbreak.” AP NEWS, 28 Jan. 2020. apnews.com, https://apnews.com/afs:Content:8443220001. Accessed 15 Feb. 2021.

Lammes, Sybille. "Postcolonial Playgrounds: Games as Postcolonial Cultures.” Eludamos: Journal for Computer Game Culture, vol. 4, no. 1, 2010, pp. 1-6.

Lamont, Michèle, et al. "Trump's Electoral Speeches and His Appeal to the American White Working Class." The British Journal of Sociology, vol. 68, no. S1, 2017, pp. S153-80. 
Magnet, Shoshana. "Playing at Colonization: Interpreting Imaginary Landscapes in the Video Game Tropico." Journal of Communication Inquiry, vol. 30, no. 2, Apr. 2006, pp. 142-62.

Malkowski, Jennifer, and TreaAndrea M. Russworm, editors. Gaming Representation: Race, Gender, and Sexuality in Video Games. Indiana UP, 2017.

McGreal, Chris. "Trump's Anti-Immigrant Rhetoric Could Lose Republicans the 2016 Election." The Guardian, 14 Sept. 2015. www.theguardian.com, https://www.theguardian.com/us-news/2015/ sep/14/donald-trump-anti-immigrant-2016-election-republican-loss. Accessed 20 Feb. 2021.

Messner, M. A. “The Limits of 'The Male Sex Role': An Analysis of the Men's Liberation and Men's Rights Movements' Discourse.” Gender \& Society, vol. 12, no. 3, June 1998, pp. 255-76.

Montanaro, Domenico. “Hillary Clinton's ‘Basket of Deplorables,' In Full Context Of This Ugly Campaign.” NPR.Org, 10 Sept. 2016. www.npr.org, https://www.npr.org/2016/09/10/493427601/ hillary-clintons-basket-of-deplorables-in-full-context-of-this-ugly-campaign. Accessed 20 Feb. 2021.

Morra, Joanne, and Emma Talbot. "Intimacy Unguarded: How the Personal Becomes Material." Journal of Visual Art Practice, vol. 16, no. 3, Sept. 2017, pp. 159-62.

Mukherjee, Souvik. Videogames and Postcolonialism. Palgrave Macmillan, 2017.

Murray, Soraya. "Horizons Already Here: Video Games and Landscape.” Art Journal, vol. 79, no. 2, June 2020, pp. 42-113.

-----. "Landscapes of Empire in Metal Gear Solid V: The Phantom Pain." Critical Inquiry, vol. 45, no. 1, Sept. 2018, pp. 168-98.

---. On Video Games: The Visual Politics of Race, Gender and Space. I. B. Tauris, 2018.

Rosin, Hanna. The End of Men: And the Rise of Women. Riverhead Books, 2013.

Russworm, TreaAndrea M. "A Call to Action for Video Game Studies in an Age of Reanimated White Supremacy." The Velvet Light Trap, vol. 81, no. 1, Feb. 2018, pp. 73-76.

Schoppmeier, Sören. "Playing to Make America Great Again: Far Cry 5 and the Politics of Videogames in an Age of Trumpism." Current Objectives of Postgraduate American Studies, vol. 20, no. 1 , June 2019, pp. 6-23.

Schreier, Jason. “Days Gone Is Basically AAA Video Games: The Video Game.” Kotaku, https:// kotaku.com/days-gone-is-one-aaa-ass-video-game-1833092908. Accessed 26 Aug. 2019.

Staiger, Janet, et al. "Political Emotions and Public Feelings." Political Emotions, Routledge, 2010, pp. 1-17.

Stiglitz, Joseph E. Globalization and Its Discontents Revisited: Anti-Globalization in the Era of Trump. Norton, 2017.

UAL. “Joanne Morra." UAL: University of the Arts London, 21 Mar. 2019. https://www.arts.ac.uk/ research/ual-staff-researchers/joanne-morra. Accessed 15 Feb. 2021.

Whitehead, Nathan, 'Creating the Soundtrack for Days Gone', PlayStation.Blog, $2019<$ https:// blog.us.playstation.com/2019/05/15/creating-the-soundtrack-for-days-gone/> Accessed 24 May 2020.

Webster, Andrew. "Days Gone Is a Lavishly Produced, Painfully Generic PS4 Zombie Game.” The Verge, 25 Apr. 2019, https://www.theverge.com/2019/4/25/18514683/days-gone-review-ps4open-world-zombie-game. Accessed 20 Jan. 2021. 


\section{NOTES}

1. I refer to an art historical discourse of landscape as illustrating ideological relations to the land, and particularly as an extension of the program of Western Expansion, such as the work of the Hudson River School in the mid- $19^{\text {th }}$ century. For more on this, see Murray, "Landscapes of Empire in Metal Gear Solid V"; Murray, "Horizons Already Here."

2. For more on the gendering of games, see Chess.

3. Thanks to Irene Fubara-Manuel for this great observation during my presentation of this material at the University of Sussex in November 2020.

4. This is revealed in a tracking training session between Copeland and Deacon St. John in a cut scene within a section called "It's a Rifle, Not a Gun." In their conversation, Copeland is revealed to be a former Marine, and Deacon former Army.

5. The term "militarized masculinity," which is connected to "mastery, domination, and conquest" as values in games, is explored to great effect in Kline et al.

6. For an excellent analysis of Trumpism as it relates to video games, particularly Ubisoft's Far Cry 5 (2018), see Schoppmeier.

7. See also Stefan Schubert's contribution to this special issue.

\section{ABSTRACTS}

This essay models a method for understanding political affect in video games by analyzing the American action-adventure survival horror game Days Gone (SIE Bend Studio, 2019). Through an examination of its rendering of the Pacific Northwest landscape as ideology, much is revealed about a deeply troubled and oppositional worldview. While this research addresses matters of representation-particularly notions of fraught masculinity and a struggle for recognition-its focus is on how the game functions as a window onto a fantasy of American self-reliance and populism that strongly resonates with a Trump-era nationalist turn in the U.S. The essay also gestures toward a methodology of experiential close-reading, one focused on working-through and sitting with a difficult aesthetic object that may at first seem entirely generic. In this essay, the author reaches through the offending, formulaic image to grasp the political affect that emanates from a sustained aesthetic experience of playing Days Gone.

\section{INDEX}

Keywords: Days Gone, video games, videogames, affect, political affect, self-reliance, separatism, ideology, whiteness, masculinity, politics, libertarian 


\section{AUTHOR}

\section{SORAYA MURRAY}

Soraya Murray is an interdisciplinary scholar of visual culture, with particular interest in contemporary art, film and video games. Murray holds a Ph.D. in art history and visual studies from Cornell University. An Associate Professor in the Film \& Digital Media Department at the University of California, Santa Cruz, Murray studies media representations (such as the playable simulations of video games), as well as the representations of advanced technology, science and innovation in film and visual culture. Murray's writings are published and anthologized nationally and internationally. Murray's first book, On Video Games: The Visual Politics of Race, Gender and Space (I.B. Tauris, 2018), focuses on post-9/11 era mainstream games and considers how they both mirror and are constitutive of larger societal fears, dreams, hopes and even complex struggles for recognition. 